\title{
Access and Openness in Biotechnology Research Collaborations between Universities and Industry
}

\author{
Egelie, Knut Jørgen; Lie, Haakon Thue; Grimpe, Christoph; Sørheim, Roger
}

\author{
Document Version \\ Accepted author manuscript \\ Published in: \\ Nature Biotechnology \\ DOI: \\ $10.1038 / s 41587-019-0324-7$ \\ Publication date: \\ 2019 \\ License \\ Unspecified
}

Citation for published version (APA):

Egelie, K. J., Lie, H. T., Grimpe, C., \& Sørheim, R. (2019). Access and Openness in Biotechnology Research Collaborations between Universities and Industry. Nature Biotechnology, 37(12), 1413-1419.

https://doi.org/10.1038/s41587-019-0324-7

Link to publication in CBS Research Portal

\section{General rights}

Copyright and moral rights for the publications made accessible in the public portal are retained by the authors and/or other copyright owners and it is a condition of accessing publications that users recognise and abide by the legal requirements associated with these rights.

\section{Take down policy}

If you believe that this document breaches copyright please contact us (research.lib@cbs.dk) providing details, and we will remove access to the work immediately and investigate your claim.

Download date: 26. Apr. 2023
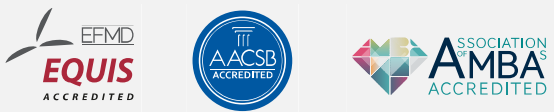


\section{Access and Openness in Biotechnology Research Collaborations between Universities and Industry}

\section{Knut Jergen Egelie, Haakon Thue Lie, Christoph Grimpe, and Roger Sørheim}

Journal article (Accepted manuscript*)

\section{Please cite this article as:}

Egelie, K. J., Lie, H. T., Grimpe, C., \& Sørheim, R. (2019). Access and Openness in Biotechnology Research Collaborations between Universities and Industry. Nature Biotechnology, 37(12), 14131419. https://doi.org/10.1038/s41587-019-0324-7

\section{DOI: $10.1038 / s 41587-019-0324-7$}

Uploaded to CBS Research Portal in accordance with the self-archiving policy of Nature Research

* This version of the article has been accepted for publication and undergone full peer review but has not been through the copyediting, typesetting, pagination and proofreading process, which may lead to differences between this version and the publisher's final version AKA Version of Record.

Uploaded to CBS Research Portal: May २०२० 


\title{
ACCESS AND OPENNESS IN BIOTECHNOLOGY RESEARCH COLLABORATIONS BETWEEN UNIVERSITIES AND INDUSTRY - AN EMPIRICAL STUDY
}

\author{
Knut Jørgen Egelie a, b, d, Haakon Thue Lie ${ }^{\text {a, b, e }}$, Christoph Grimpe ${ }^{c}$, Roger Sørheim ${ }^{\text {a }}$ \\ ${ }^{\mathrm{a}}$ Norwegian University of Science and Technology (NTNU), ${ }^{\mathrm{b}}$ Center for Intellectual Property \\ (CIP ), ${ }^{\mathrm{c} C o p e n h a g e n ~ B u s i n e s s ~ S c h o o l ~(C B S), ~}{ }^{\mathrm{d}}$ NTNU TTO AS, ${ }^{\mathrm{e}}$ Leogriff AS,
}

\begin{abstract}
Biotechnology research can spawn broadly useful technology research platforms such as CRISPR/Cas9, which has frequently been criticised as a knowledge monopoly. The access to such technology can be restricted, and utilisation of research results depends on the contractual provisions devised by the owners of the technology. It is therefore imperative to better understand the conditions under which knowledge monopolies are likely to emerge. Based on the analysis of 162 publicly funded collaborative research projects in biotechnology, we identify contractual provisions that govern the extent of access to and openness of research results. We evaluate how the project participants in free negotiations agree on ownership and user rights from intellectual property, as well as on confidentiality and publication rights. We develop a framework that identifies four cases - knowledge monopoly, attenuated monopoly, closed circle, and open science - that can help unravel the complicated contractual provisions and their interrelationships. The framework allows both policy makers and funding bodies to assess the likelihood of emerging knowledge monopolies ex-ante in order to assess the norms of open science versus the utilisation of the research results.
\end{abstract}

Keywords: knowledge monopolies, open science, publicly funded research, universityindustry collaboration, biotechnology, access, openness 
Prepress version - to be published in Nature Biotechnology, December 2019

\section{INTRODUCTION}

Collaboration in research between universities and industry is essential for academic knowledge to be channelled into the industrial domain ${ }^{1}$. Firms benefit from accessing complementary scientific knowledge that they can use to enhance the quality of their inventions, to realise efficiency gains for business $R \& D$, and to anticipate future research problems in new technological areas ${ }^{2,3}$. There is evidence that industry participation in or sponsorship of academic research frequently limits the disclosure and further development of research results, methods, or materials. By delaying their public release, sometimes even beyond the time needed to file a patent, firms strive to secure private financial returns ${ }^{4-8,9}$ Table

$\mathrm{v}$. Secrecy and the allocation of ownership and exploitation rights to firms in collaborative research may, therefore, jeopardise the norms of "open science". These norms support an efficient and welfare-enhancing paradigm for creating a cumulative, reliable, and publicly available stock of scientific and technical knowledge $\mathrm{e}^{3,10}$.

Recent developments suggest, however, that firms may not be the only ones promoting secrecy and decreasing support of open science. Since the Bayh-Dole Act in the US and similar legislation in most European countries have come into force several decades ago, universities increasingly seek glory in both academic research and successful commercialisation of research results ${ }^{1}$. To do so, they need control over the intellectual property (IP). Patenting the research results, or keeping them secret, may however lead to knowledge monopolies in broadly useful technologies. Patents that emerge from winner-takeall races are not only likely to hamper downstream development; they can also encourage upstream duplication, which undermines the cumulative advances in scientific knowledge production $^{11}$.

The controversy around some of the essential patents on the CRISPR technology is one case in point ${ }^{11}$. The University of California, Berkeley, and the Broad Institute have been 
Prepress version - to be published in Nature Biotechnology, December 2019

in disputes in the US and Europe over patent rights associated with the CRISPR/Cas9 construct. They have also developed strong commercial interests by taking equity in start-up companies that seek to commercialise applications of CRISPR/Cas9 for which they have received exclusive licences from the universities ${ }^{12,13}$. It seems provocative that research underlying the CRISPR technology was funded by the US National Institutes of Health, socialising the cost and risk of research while privatising the financial returns ${ }^{14}$. In that sense, the CRISPR/Cas9 case highlights the tensions arising from the changing mission of universities. At the same time, our understanding is limited to what extent research in biotechnology beyond the prominent cases leads to the emergence of knowledge monopolies. A substantial share of public funding targets collaborative research, i.e. consortia of universities, industry and other participants. It is pertinent to investigate the extent to which such research can lead to knowledge monopolies or variants thereof.

A requirement that most funding bodies impose on research consortia is that the partners involved in joint research set up a collaboration agreement that governs, among other aspects, how the partners seek to deal with research results and the associated IP in a way that complies with the rules and regulations put forward by the funding body ${ }^{15}$. In this study, we focus on the contractual agreements that the range of partners in research collaborations, which feature at least one university and one industry partner, have negotiated among themselves. These agreements usually remain undisclosed. Our study exploits a unique opportunity to gain an in-depth understanding of the negotiated outcomes specified in such contractual agreements. Based on an analysis of the full text of the contractual agreements of 162 biotechnology projects funded by the Research Council of Norway (RCN) in the period from 2009 to 2017, we code the provisions associated with the handling of IP. From this, we determine whether the outcome of a research project is likely to end in a knowledge monopoly. Specifically, we argue that knowledge monopolies that stifle open science are 
Prepress version - to be published in Nature Biotechnology, December 2019

related to questions on access to and openness of research results. Prior research has typically lumped these two dimensions together in the absence of more detailed information. In that sense, we define access as the control over ownership and commercial use rights of research results while openness refers to restrictions in the flow of knowledge in terms of publication rights and confidentiality. Access and openness are typically intertwined dimensions.

Concentrated or dispersed access as, for example, in the case of exclusive versus nonexclusive licensing, may go along with low or high degrees of openness as, for instance, in case of broad versus restricted publication rights or confidentiality provisions. In that regard, we seek to identify the provisions around access and openness, which attenuate or aggravate knowledge monopolies in collaborative biotechnology research projects.

\section{CONTRACTUAL AGREEMENTS GOVERNING ACCESS AND OPENNESS}

The contractual agreements of research consortia are complex documents and the terminology used in prior literature to describe contractual provisions varies. For our study, we are interested in two dimensions. First, the agreements regulate the ex-post access to research results, specifying the ownership of the results as well as the distribution of the rights to all commercial uses of the IP. The background rights on IP that the parties bring to the project are important too, but they are typically not negotiated. It is uncontroversial that the party bringing IP to the project keeps that control. Second, the agreements regulate the openness of the research results, that is the conditions under which the knowledge may be disclosed, specifying provisions on confidentiality and publication.

Related literature, such as Lerner and Merges, uses the term "control rights" in their study of alliances between biotechnology and pharmaceutical firms ${ }^{9}$. Some of these control rights concern our understanding of access, such as patent ownership and the use rights, while others refer to openness, such as the right a party has to delay or ban publication. Contrary to Lerner and Merges, our study is set in the early phase of innovation, in which some control 
Prepress version - to be published in Nature Biotechnology, December 2019

rights are not yet relevant. Examples include the right to manage clinical trials or to market the product. Also, the term "control rights" emphasises the need a private sponsor of outsourced research has to protect that investment. In our setting of publicly sponsored university-industry collaborations, an objective for the collaborations is the best public utilisation of the results. The collaborating partners are more in need of access to the results than control over the other partners. A more suitable terminology is in a study from Stevens et al. that concerns early-phase research in public-private partnerships. The authors use "access rights" related to use rights of background, sideground (results that are outside the scope of the project) and foreground (the results within the scope), and distinguish them from ownership ${ }^{16}$. Following Stevens et al., our understanding of access concerns both ownership and use rights. Ownership refers to the ability to control and manage access to the IP while use rights are more condensed and mostly refer to the opportunities for commercial utilisation, both exclusively and non-exclusively, as well as the right to use the IP for further research.

Insights from prior literature on the access to research results and IP have been mixed. For example, while Walsh et al. document an increase in patents on the inputs to drug discovery, they find few indications that university research has been hampered by concerns about patents on research tools ${ }^{17}$. However, Lei et al. conclude from a survey of agricultural biologists that IP protection of research tools has a strongly negative effect ${ }^{18}$ on access. From another point of view, Egelie et al. discuss the positive role of IP in view of the ethical obligations universities have for giving access to research platforms such as CRISPR ${ }^{13}$. More broadly, a study on research consortia in the life sciences concludes that the consortium partners' policies on IP often lack transparency, with few having clear and defined frameworks, which in turn impedes the access to $\mathrm{IP}^{16}$. 
Prepress version - to be published in Nature Biotechnology, December 2019

Moreover, prior research has frequently documented that industry as a sponsor of academic research or a partner in collaborative research often prefers secrecy over disclosure to increase the appropriability of the returns to the research performed ${ }^{4-7,19,20}$. Publication of the results may be delayed or banned in parts in exchange for the contribution that industry makes to the research project ${ }^{8,21,22}$. The agreements in our study confirm that some projects may have provisions for keeping research results secret, see Figure 3: Description of the contractual provision measures. Conversely, universities and the individual scientists have historically had a strong interest in disclosure through publication. Merton famously characterised the modern scientific system as distinct from other social systems due to the importance of sharing ${ }^{23}$. Because of the enactment of Bayh-Dole and similar legislation in other countries as well as the proximity of science and technology in disciplines such as biotechnology, the attitudes of universities and university scientists towards disclosure versus secrecy have become less straight-forward. In that sense, universities may - similar to industry - show an interest in using various IP rights such as trade secrets or patents to appropriate the results from collaborative projects $^{24}$.

The two dimensions of access and openness suggest that the contractual provisions in research projects, therefore, imply the existence of variants in how knowledge and IP are handled, ranging from knowledge monopolies with concentrated access rights and low openness at one extreme, to open science at the other. Figure 1 shows a simplified account of such variants, depending on how they score regarding their contractual provisions on the two dimensions of access and openness. Collaborative projects differ in the extent to which the ownership and use rights are either concentrated or dispersed. Concentrated access describes a situation in which one or a few of the collaboration partners own the results and have the exclusive use rights, while non-exclusive licencing indicates dispersed access. Research projects also differ on the degree of openness, that is the extent to which the contractual 
Prepress version - to be published in Nature Biotechnology, December 2019

provisions allow research results to be kept as trade secrets or require that the results are disclosed and published.

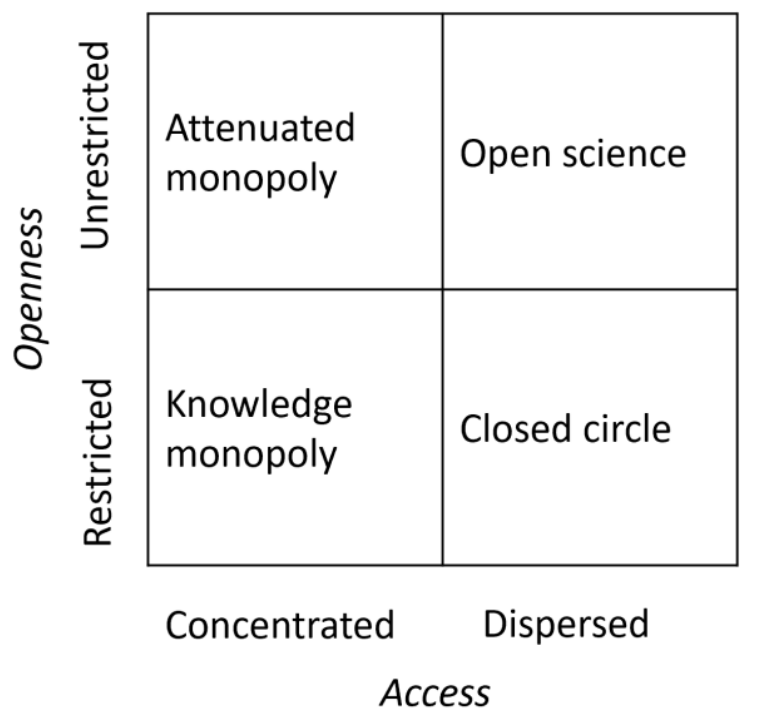

Figure 1: A model with access and openness

We argue that a "knowledge monopoly" can emerge if access rights are concentrated and if the openness of research results is low. In this case, the ownership and use rights lie in few hands, all licencing is exclusive, and there are trade secrets and publication restrictions. There may be limited licensing opportunities for organisations outside the focal collaborative project. Moreover, secrecy is prioritised over disclosure, possibly even beyond the time needed to file a patent. In a second case, contractual provisions may stipulate concentrated access rights while making knowledge public and easily searchable. We refer to this situation as an "attenuated monopoly" in which knowledge is controlled with IP rights, but published and open. Here, the openness provisions would likely reduce the extent to which upstream research may be duplicated. As there is no secrecy, the typical appropriation mechanisms are patents, material transfer agreements, database rights and copyright for software. A third case that we refer to as "closed circle" is described by a non-exclusive dispersion of access rights while openness remains low. This case may, for example, refer to a research result, such as a 
Prepress version - to be published in Nature Biotechnology, December 2019

proprietary source code, that remains under non-disclosure agreements, yet is licensed out to those who ask for it. "Closed circle" resembles the concept of "club goods" from economic theory $^{25}$. Finally, a combination of dispersed access and high openness leads to a situation that is within the norms of "open science". It comprises use rights for all that ask, for example under licenses similar to open-source software. In addition, the research results are well-documented, publicly available and searchable. A university could, for example, provide access for anyone wishing to utilise a technology, with a non-exclusive licence on nondiscriminatory terms. Such licencing is for example how the recombinant DNA and the cotransformation of eukaryotic DNA were transferred from the universities involved in the $\operatorname{research}^{12,26}$.

\section{DATA AND METHODS}

\section{Data}

Our study uses data from 162 biotechnology research projects co-sponsored by the Research Council of Norway (RCN) over the period from 2009 to 2017. Every year, the RCN provides research funding of about 1 billion euro to projects spanning all areas of technology and scientific disciplines. Our sample is drawn from a total population of 21,838 projects that received public funding during that period. We restricted our sampling to those projects in the field of biotechnology that included at least one university and one industry partner. From these, we randomly selected projects for inclusion in the analysis. We excluded projects with insufficient information on variables of interest. The Norwegian Ministry of Trade, Industry and Fisheries and the RCN allowed us to research data on participants, funding amounts, and the collaboration agreement documents that the partners signed with the $\mathrm{RCN}$ and with each other. The share of funding provided by the RCN to these projects varies between $22 \%$ and $100 \%$. In total, there are 1348 agreements among the partners of the 162 projects. That is, 
Prepress version - to be published in Nature Biotechnology, December 2019

there are typically multiple agreements per project. The agreement documents are our sole source of information on the contractual provisions between project partners.

The collaboration agreements are comparable in length and structure. They are governed by RCN's contract management, including policy documents, the general terms of funding, and are based on several templates, or "boilerplate" agreements for collaborative research projects. While agreements based on RCN's contract templates represent $59 \%$ of the projects in our data, the collaboration partners are free to introduce new provisions or to modify the suggested provisions.

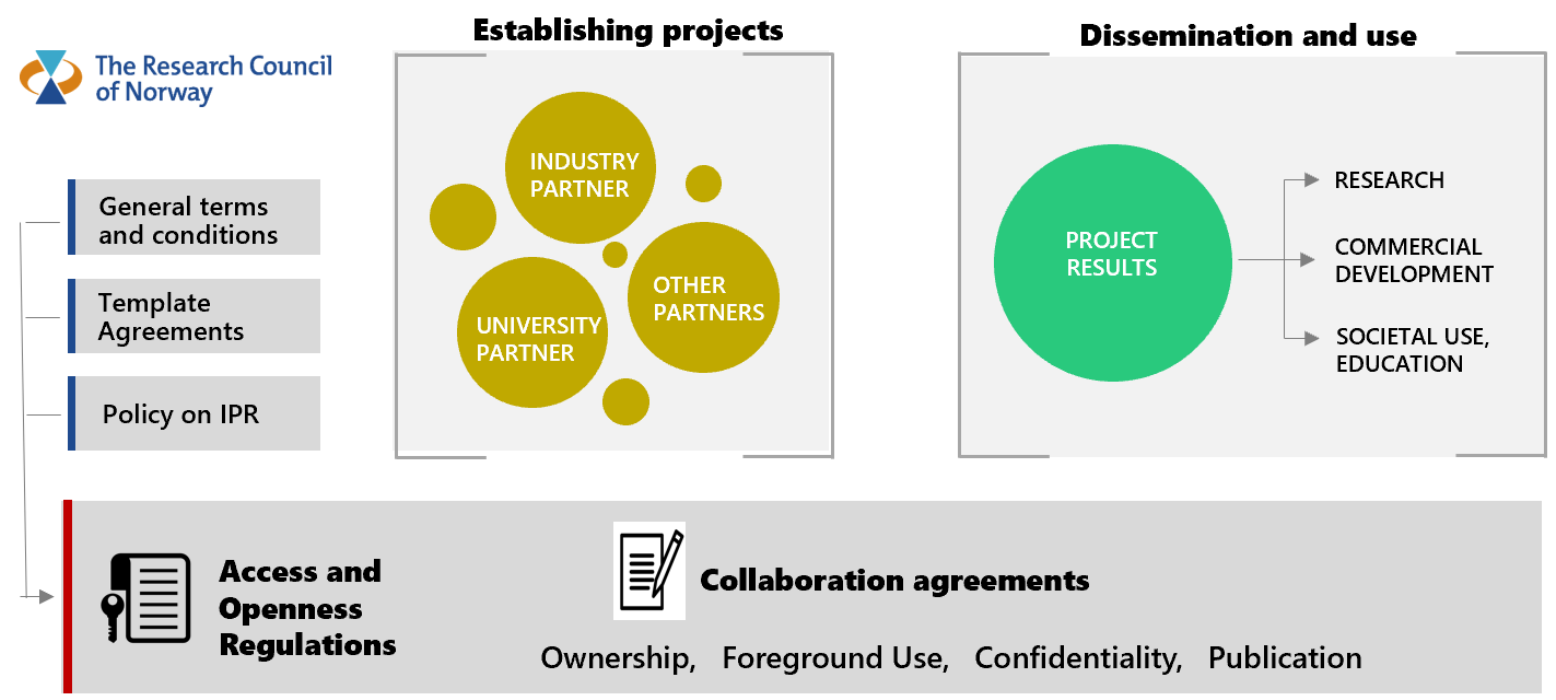

Figure 2: The RCN contract management and our study

Figure 2 shows the RCN's rules and regulations that provide a framework for the contractual provisions. However, the parties negotiate freely. Except for some aspects involving the distribution of rights in the projects, the RCN does not have special requirements for the scope, format or content of the collaboration agreements. The collaboration agreements are drafted in the initial phases of the project and govern the mutual rights and obligations of the project coordinator and the other partners in the project. The RCN communicates directly with the project coordinator only and is not a contractual party to the collaboration 
Prepress version - to be published in Nature Biotechnology, December 2019

agreements. In our sample, $30 \%$ of the projects were coordinated by industry, $31 \%$ by universities or university hospitals and $38 \%$ by research institutes. The role of being the project coordinator does not necessarily reflect a stronger position in the negotiations of the terms but rather indicates administrative capacity or requirements. The coordinator may choose to have a multi-lateral or joint agreement or individual and bi-lateral collaboration agreement with each partner. In our sample, $73 \%$ of the projects had jointly-signed multilateral collaboration agreements. Each project partner is responsible to the project coordinator, and the coordinator is responsible to the $\mathrm{RCN}^{15}$. Our analysis does not extend to evaluating actual project results, only the intentions of the partners as stipulated in the contractual provisions.

\section{Variables and measures}

\section{Contractual provisions}

The measurement of contractual provisions regarding the access to and openness of research results from publicly funded research projects is implemented using a coding scheme applied to the collaboration agreements of the consortia. We developed the coding scheme in an iterative process, starting with an initial investigation of the common terms and expressions used in the agreements. We compared them with common clauses, terms and terminology used in templates of the RCN as well as other funding organisations in the European Research Area ${ }^{15,16,27-30}$. Our scheme contains a similar set of IP related provisions as found in Stevens et al. ${ }^{16 \text { Box 1, p.505 }}$. We noted that the terms and level of detail used in European contract templates are different from contracts used in the U.S. and the provisions of the Bayh-Dole act ${ }^{9,31}$. However, the terminology used in both Europe and the U.S. allows a distinction between access rights and openness, which we introduced in Figure 1: A model with access and openness. 
Prepress version - to be published in Nature Biotechnology, December 2019

We focus on four sets of contractual provisions that, while not entirely independent from each other, can be identified and delineated; provisions regarding the ownership of research results, provisions affecting the distribution of control rights to the commercial use of IP, provisions regarding dissemination and publication of project results, and provisions influencing the degree of confidentiality. Next, we scored the relative strength of each of the four sets of provisions based on pattern similarities in formulations of contractual terms and language. Table 1 shows the coding scheme. The formulations do not necessarily reflect actual formulations in the collaboration agreements but rather group similar and comparable formulations in order to reduce the degree of complexity that the study of idiosyncratic contracts involves.

\begin{tabular}{|c|c|c|c|c|c|}
\hline \multicolumn{3}{|c|}{ ACCESS } & \multicolumn{3}{|c|}{ OPENNESS } \\
\hline & Ownership & \multirow{2}{*}{$\begin{array}{l}\text { Commercial use rights } \\
\text { Industry partner has exclusive use } \\
\text { rights to all commercial use of IP } \\
\text { and project results }\end{array}$} & \multirow{2}{*}{$\begin{array}{l}\text { Publication } \\
\text { All dissemination of project results is } \\
\text { strictly controlled. No publications } \\
\text { allowed }\end{array}$} & \multicolumn{2}{|l|}{ Confidentiality } \\
\hline 1 & $\begin{array}{l}\text { Industry partner owns all IP and } \\
\text { project results }\end{array}$ & & & $\begin{array}{l}\text { All information is by default } \\
\text { confidential if not already public. No } \\
\text { specified timeframe or other } \\
\text { limitations }\end{array}$ & 1 \\
\hline 2 & $\begin{array}{l}\text { A specific party owns project results if } \\
\text { based on own background, } \\
\text { dominating contribution or own } \\
\text { commercial interests. Otherwise } \\
\text { jointly owned }\end{array}$ & $\begin{array}{l}\text { All parties have by default exclusive } \\
\text { use rights within specified field or } \\
\text { non-exclusive, world-wide, royalty } \\
\text { free in all fields }\end{array}$ & $\begin{array}{l}\text { Project results must be published but } \\
\text { could be delayed according to } \\
\text { participants' needs }\end{array}$ & $\begin{array}{l}\text { All project results and background } \\
\text { information disclosed are by default } \\
\text { confidential if not already public, } \\
\text { limited in time }\end{array}$ & 2 \\
\hline 3 & $\begin{array}{l}\text { All project results are jointly owned. } \\
\text { Separate agreements for commercial } \\
\text { use rights }\end{array}$ & $\begin{array}{l}\text { All parties granted non-exclusive use } \\
\text { rights to all project results to be able } \\
\text { to utilise own project result }\end{array}$ & $\begin{array}{l}\text { Results shall be published, but } \\
\text { publication must be sent to steering } \\
\text { committee which could object and } \\
\text { request modifications before } \\
\text { publication }\end{array}$ & $\begin{array}{l}\text { Project results and background } \\
\text { information are confidential if } \\
\text { marked, justified and limited in scope } \\
\text { and time }\end{array}$ & 3 \\
\hline 4 & $\begin{array}{l}\text { A specific project partner retains } \\
\text { ownership of all project results. } \\
\text { Where several parties have carried } \\
\text { out work generating project results } \\
\text { and where share of the work cannot } \\
\text { be ascertained, they have joint } \\
\text { ownership }\end{array}$ & $\begin{array}{l}\text { All parties have royalty free use } \\
\text { rights, but only during the project } \\
\text { period to results that are needed to } \\
\text { utilise own project result. Further } \\
\text { use rights may be given upon } \\
\text { request }\end{array}$ & $\begin{array}{l}\text { Publications could be delayed due to } \\
\text { patenting or other justified grounds, } \\
\text { but according to national laws. Clearly } \\
\text { stated that results must be published } \\
\text { within a time frame }\end{array}$ & $\begin{array}{l}\text { Project partners have to specifically } \\
\text { request confidentiality. Information } \\
\text { must be marked confidential, time } \\
\text { limited and approved by steering } \\
\text { committee. Parties could refuse }\end{array}$ & 4 \\
\hline 5 & $\begin{array}{l}\text { Academic partner owns all IP and } \\
\text { project results }\end{array}$ & $\begin{array}{l}\text { Only academic partner has specified } \\
\text { use rights to project results }\end{array}$ & $\begin{array}{l}\text { No publication restriction. Specified } \\
\text { that results must be published }\end{array}$ & No terms on confidentiality specified & 5 \\
\hline
\end{tabular}

Table 1: The coding scheme including typical contractual clauses

Next, two members of the research team experienced in the analysis of contracts jointly coded the agreements from 30 collaboration projects according to the coding scheme. They discussed their respective coding decisions as well as cases of doubt. In general, and mostly 
Prepress version - to be published in Nature Biotechnology, December 2019

because many consortia used standard formulations from the templates, there were very few discrepancies in the coding decisions between the two coders. For that reason, the remainder of the agreements is coded independently, resolving cases of doubt through discussions.

In order to map the projects to the matrix described in Figure 1, we created two dummy variables measuring access and openness of the projects. The first variable, access, is assigned a value of one if the projects are coded as having dispersed ownership or dispersed use rights (i.e. commercial rights to use of the foreground, the research results) and zero otherwise. All other codings in Table 1 either indicate concentrated ownership and use rights on the side of the industry or university partners, or they lean towards concentration. The variables for publication and confidentiality can be understood as ordinal. We create the second dummy variable, openness, by running a factor analysis to aggregate the two variables. Both variables are positively correlated $(\mathrm{r}=0.4558)$ and load highly on a joint factor variable $(\mathrm{r}=0.8532)$. The factor variable (with a mean of zero and a standard deviation of one) accounts for $72.79 \%$ of the variance. Subsequently, we split the variable at and including the median to create a dummy variable that measures the openness of a project's research results. The variable takes the value of one if the factor variable score is higher or at the median and zero otherwise.

\section{Project characteristics}

We define several other variables describing project characteristics based on information provided by the RCN. First, we count the total number of partners in a project as well as the different types of partners, showing the share of firms and the share of universities in the projects. Next, we use the RCN funding share as a variable that measures the share of the total project budget that was sponsored by the RCN. We also create dummy variables, measuring whether the project coordinator is a university or not and whether the project type 
Prepress version - to be published in Nature Biotechnology, December 2019

can be characterised as "research" as opposed to "commercial" or "other" as indicated by the RCN. Moreover, we measure the total project budget in millions of NOK.

\section{Empirical approach}

Our empirical analysis starts by presenting four exemplary projects out of the 162 projects to illustrate the different concepts depicted in Figure 1. Next, we show descriptive evidence on the 162 biotechnology projects under study. We then present the results of an analysis of variance (ANOVA) on the project characteristics variables that we compare by group.

\section{EXEMPLARY CASES}

Due to the confidential nature of the agreements, we do not reveal details on the contracts and their contractual provisions while mapping them to the four cases in Figure 1. The cases are from our sample but anonymised.

\section{Knowledge monopoly - project "Medical imaging"}

This project is an innovation project with a budget of around 4 million euro. The RCN funds around one-third of the project. It runs over several years and is composed of two universities, three industrial partners (all but one from Norway), and research institutes. One of the industry partners serves as the project coordinator. All results are owned by the coordinator, and all commercial use rights are exclusive and to be used by the coordinator. Moreover, all publications are controlled by the coordinator who also has the right to request changes of any manuscript before publication. The results are a mix of applied research and commercial results to which the coordinator has privileged access.

\section{Attenuated monopoly - project "Energy from biomaterial"}

This project is a large environmental research project with a budget of more than 10 million euro. The RCN funds about half of the project. The project runs for almost a decade and has five university partners and around 20 industry partners, most of them from Norway. There 
Prepress version - to be published in Nature Biotechnology, December 2019

are also research institutes involved, one of which is the project coordinator. All results are owned by the coordinator, and all commercial user rights are exclusive and to be used by the coordinator. Even though the publication of the results is allowed and encouraged, the clauses on confidentiality are strict. The results are a mix of basic and applied research as well as commercial results. In that sense, the contractual provisions point towards concentrated access while allowing for somewhat controlled dissemination.

\section{Closed circle - project "Prevention of fungal infections"}

This project can be characterised as a larger innovation consortium comprising only two university partners, but many industry partners and some institutes. The total budget of the project is about 5 million euros of which the RCN is funding half. It runs for only two years. One of the industry partners coordinates the project. The ownership of research results would be either by one partner if created by that partner alone or jointly owned otherwise. All partners shall have access to the commercial use of results if desired. Publication is desired and encouraged, but the steering committee can impose publication delays to facilitate the protection of IP or if the commercial value of the project result could be reduced.

\section{Open science - project "Food and plant production"}

This project has four participants, one university, two industry partners and one institute; all are from Norway. It has a budget of around 5 million euros of which the RCN funds around $80 \%$. The institute partner is the project coordinator. Each participant is granted ownership rights and all IP to project results produced by participants individually. Project results shall also be published as soon as possible. The objective of the project is to create and explore different research tools without concrete considerations for innovation and commercialisation. In that sense, the contractual provisions closely follow the norms of open science. 
Prepress version - to be published in Nature Biotechnology, December 2019

\section{RESULTS}

In a first step, we are interested in characterising the RCN funded biotechnology projects regarding their contractual provisions to determine their approach to access and openness of research results. Figure 3 shows descriptive statistics. With regard to the ownership of research results, we find that in most of the cases ownership tends to be concentrated with the university partners (categories 4 and 5, i.e. $61 \%$ ) or the industry partners (categories 1 and 2 , i.e. $25 \%$ ). Joint ownership is rather uncommon, as it is only used in $14 \%$ of the projects as the intermediate category shows. Concerning the distribution of use rights, we find that joint use rights are the dominant mode with about $46 \%$ of the cases. Exclusive use rights for the industry partners (categories 1 and 2, i.e. 28\%) and university partners (categories 4 and 5, i.e. $25 \%$ ) are relatively less frequent. The indication is that, while ownership is typically concentrated, use rights are more dispersed. Combining the two variables, we find that in $51 \%$ of the projects there are either joint ownership or joint use rights. Turning to the contractual provisions regarding publication and confidentiality, we find that both variables for most projects show intermediate values, indicating that most projects include some confidentiality clauses and publication restrictions. 
Prepress version - to be published in Nature Biotechnology, December 2019

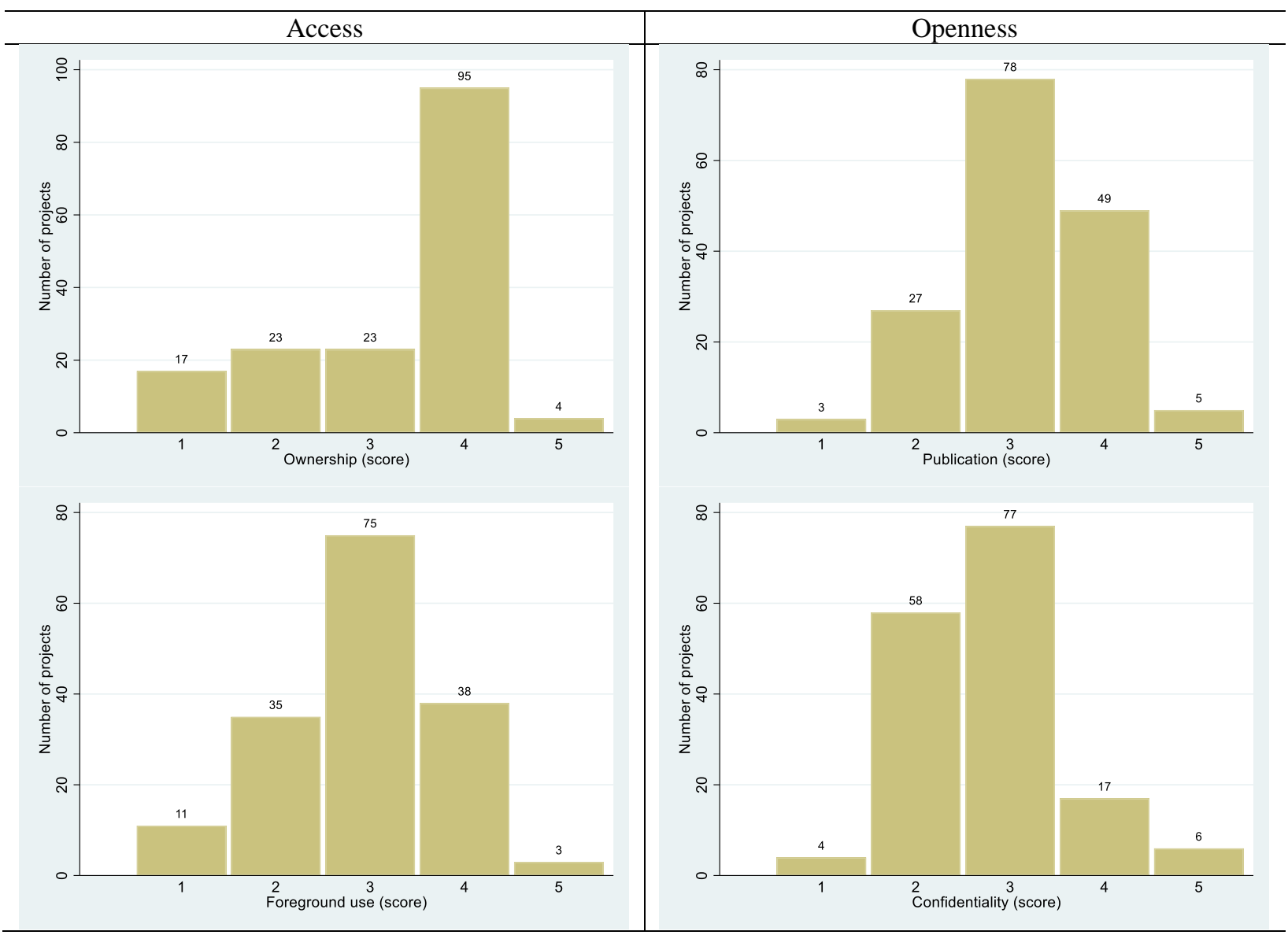

Figure 3: Description of the contractual provision measures

Next, we cross-tabulate the two dummy variables on access and openness that are based on the four types of contractual provisions.

Figure 4 shows the results. We find that $17 \%$ of the projects are characterised by contractual provisions increasing the likelihood of the emergence of knowledge monopolies. In contrast, $32 \%$ of the projects feature contractual provisions that resemble more the principles of open science. The remainder of the projects is characterised by either restricted openness or concentrated access. The attenuated monopoly, featuring contractual provisions that indicate a high degree of openness, yet concentrated ownership, includes $32 \%$ of the projects while the closed circle, characterised by low openness but dispersed access rights, includes $19 \%$ of the projects. 
Prepress version - to be published in Nature Biotechnology, December 2019

\begin{tabular}{|c|c|c|c|}
\hline & 80 & 82 & 162 \\
\hline & $49.4 \%$ & $50.6 \%$ & $100 \%$ \\
\hline 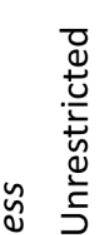 & $\begin{array}{l}\text { Attenuated } \\
\text { monopoly } \\
\mathbf{5 2} \\
\mathbf{3 2 . 1 \%}\end{array}$ & $\begin{array}{l}\text { Open science } \\
52 \\
32.1 \%\end{array}$ & $\begin{array}{l}104 \\
64.2 \%\end{array}$ \\
\hline 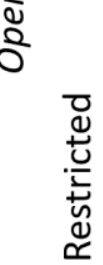 & $\begin{array}{l}\text { Knowledge } \\
\text { monopoly } \\
28 \\
17.3 \%\end{array}$ & $\begin{array}{l}\text { Closed circle } \\
30 \\
18.5 \%\end{array}$ & $\begin{array}{l}58 \\
35.8 \%\end{array}$ \\
\hline & Concentrat & Dispersed & \\
\hline
\end{tabular}

Figure 4: Cross-tabulation of access and openness in RCN funded biotechnology projects

To better understand the characteristics of the projects in the four groups, Table 2 shows the results of an analysis of variance (ANOVA) for the project characteristic variables differentiated by group. It turns out that most differences in mean values, while informative, are statistically insignificant, indicating relatively small differences between the groups. We find that projects in the knowledge monopoly group are the smallest by the number of partners involved in the project, even though closed circle projects are the smallest by total budget. Projects in the attenuated monopoly and open science group are the largest, both by the number of participants and the total budget. The institutional composition of the projects in the four groups is virtually invariant. All groups feature about the same share of firms as well as universities among the project partners. Concerning the funding share sponsored by the RCN, knowledge monopoly projects exhibit the lowest while closed circle and open science projects show the highest amount of public funding. Projects also more often feature contractual provisions regarding open science when they are coordinated by a university partner and when the project itself is funded as a research project as opposed to a development and commercialisation project. 
Prepress version - to be published in Nature Biotechnology, December 2019

\begin{tabular}{|l|c|c|c|c|c|c|c|}
\hline Variable & \multicolumn{9}{|c|}{ Mean (Std. Dev.) } & df & $\mathrm{F}$ & Prob>F \\
\hline & $\begin{array}{c}\text { "Knowledge } \\
\text { monopoly" } \\
(\mathrm{n}=28)\end{array}$ & $\begin{array}{c}\text { "Attenuated } \\
\text { monopoly" } \\
(\mathrm{n}=52)\end{array}$ & $\begin{array}{c}\text { "Closed } \\
\text { circle" } \\
(\mathrm{n}=30)\end{array}$ & $\begin{array}{c}\text { "Open } \\
\text { science" } \\
(\mathrm{n}=52)\end{array}$ & & & \\
\hline No. of partners & $6.54(3.77)$ & $9.44(5.58)$ & $7.50(3.54)$ & $8.63(4.61)$ & 3 & 2.70 & 0.0478 \\
\hline Share of firms & $0.51(0.18)$ & $0.52(0.20)$ & $0.49(0.24)$ & $0.50(0.20)$ & 3 & 0.18 & 0.9107 \\
\hline Share of universities & $0.34(0.18)$ & $0.31(0.21)$ & $0.31(0.18)$ & $0.34(0.20)$ & 3 & 0.29 & 0.8352 \\
\hline RCN funding share $(\%)$ & $57.95(22.05)$ & $63.81(20.19)$ & $70.19(22.68)$ & $66.90(22.75)$ & 3 & 1.72 & 0.1649 \\
\hline University coordinator & $0.25(0.44)$ & $0.31(0.47)$ & $0.23(0.43)$ & $0.40(0.50)$ & 3 & 1.13 & 0.3402 \\
\hline Research project & $0.11(0.31)$ & $0.25(0.44)$ & $0.30(0.47)$ & $0.35(0.48)$ & 3 & 1.88 & 0.1352 \\
\hline Total budget (mNOK) & $24.12(48.24)$ & $37.98(58.10)$ & $19.05(39.59)$ & $36.58(80.33)$ & 3 & 0.84 & 0.4747 \\
\hline
\end{tabular}

Table 2: Results of the ANOVA analysis of project characteristics

\section{DISCUSSION AND CONCLUSION}

Knowledge monopolies in broadly useful technologies are problematic, no matter whether they are controlled by academia or industry because they likely hamper downstream development and encourage upstream duplication. Prior research has argued that monopolies undermine the cumulative advances in scientific knowledge production ${ }^{11}$. With the caveat that the broad usefulness of newly developed technologies often only becomes apparent expost, our results indicate that publicly funded research does end in knowledge monopolies in a non-trivial number of cases. More importantly, we identify two variants of knowledge monopolies that may be equally harmful to follow-on research since they violate the norms of open science in one or the other form. Only about one-third of the projects in our sample subscribe to the norms of open science.

Our results hold two central insights. First, we offer a distinction between access and openness provisions that prior literature has often lumped together due to a lack of detailed information. This distinction allows systematic analysis of contractual agreements in collaborative research projects. The provisions on ownership, the distribution of use rights, publication and confidentiality, are standard elements in these types of contracts. However, their concurrence leads to different situations concerning the handling of IP in the projects, 
Prepress version - to be published in Nature Biotechnology, December 2019

which in turn holds different implications. It is a long-standing belief that patents and other IP rights limit researchers' access to breakthrough technology ${ }^{16,32,33}$. Our research supports an important qualification. We find that it is not the IP rights that restrict access but how organisations manage IP. They provide access through licenses and other types of agreements as in the case of collaborative research. Openness of the research results, i.e. disclosure and publication, factor in too. In that sense, our analysis paints a more complex picture of the reality of contractual provisions in collaborative research.

Second, our research has developed a tool that can be useful for funding bodies and policy makers. Contractual agreements can be designed and classified according to how they score with regard to access and openness. This allows stakeholders to monitor the projects. Those projects that likely lead to broadly useful technologies, similar to the CRISPR technology, could then be required to rework access and openness provisions in order to avoid knowledge monopolies. In that regard, the incentives of the universities behind the CRISPR technology to secure private financial returns could have been reigned in early by the funding bodies enabling the research in the first place. While the universities promised to allow other researchers access to the technology for academic purposes, the commercial rights are concentrated with a small number of firms in which the universities own a major stake. Several questions arise that so far have not been answered yet: What happens if other researchers make significant discoveries with commercial potential using a tool they were allowed to use for non-commercial research purposes? What opportunities do these researchers and universities have for the further use of the research results? Our conceptual model allows unravelling the complicated contractual provisions and their interrelationships in order to clarify issues like these up front and before engaging in collaborative research. Such pre-project planning could increase the quality of any collaboration agreement and, 
Prepress version - to be published in Nature Biotechnology, December 2019

more importantly, allow for more transparent handling of IP for a funding body or society at large.

\section{DATA AND CODE AVAILABILITY STATEMENT}

The results were obtained using the STATA SE Version 15.1 statistical software package. The do-file can be obtained from the authors upon request.

\section{ACKNOWLEDGEMENTS}

The authors thank the Center for Intellectual Property (CIP) at the University of Gothenburg, Chalmers University of Technology and Norwegian University of Science and Technology for insights on intellectual property platforms, as well as NORSI - the Norwegian Research School in Innovation. The authors also sincerely thank Ulf Petrusson at the University of Gothenburg and Berit Johansen at the Norwegian University of Science and Technology for supervision, and Gregory D. Graff at the Colorado State University and Wolfgang Sofka at Copenhagen Business School for valuable discussions. The following organizations have contributed as funding and supporting partners: NTNU Technology Transfer AS, Leogriff AS and The Research Council of Norway as part of Industrial Ph.D. grants 247566 and 238770. 


\section{REFERENCES}

1. Perkmann, M. et al. Academic engagement and commercialisation: A review of the literature on university-industry relations. Res Policy 42, 423-442 (2013).

2. Hall, B.H., Link, A.N. \& Scott, J.T. Universities as Research Partners. Journal of Economic Studies 85, 485-491 (2003).

3. Dasgupta, P. \& David, P. Towards a new economics of science. Research Policy 3 , 487-521 (1994).

4. Blumenthal, D., Campbell, E.G., Causino, N. \& Louis, K.S. Participation of LifeScience Faculty in Research Relationships with Industry. New England Journal of Medicine 335, 1734-1739 (1996).

5. Cohen, W.M., Florida, R., Randazzese, L. \& Walsh, J. in Challenges to research universities. (ed. R.G. Noll) 171-199 (Brookings Institution Press, Washington DC; 1998).

6. Thursby, J.G. \& Thursby, M.C. University licensing. Oxford Review of Economic Policy 23, 620-639 (2007).

7. Gans, J.S. \& Murray, F. in The Rate and Direction of Inventive Activity Revisited, Bureau of Economic Research Conference Report. (eds. J. Lerner, R. National Bureau of Economic \& S. Stern) 51-103 (University of Chicago Press, Chicago; 2012).

8. Czarnitzki, D., Grimpe, C. \& Toole, A.A. Delay and Secrecy: Does Industry Sponsorship Jeopardize Disclosure of Academic Research? Industrial and Corporate Change 24, 251-279 (2015).

9. Lerner, J. \& Merges, R.P. The control of technology alliances: An empirical analysis of the biotechnology industry. The Journal of Industrial Economics 46, 125-156 (1998).

10. Mukherjee, A. \& Stern, S. Disclosure or secrecy? The dynamics of open science. International Journal of Industrial Organization 27, 449-462 (2009).

11. Rai, A.K. \& Cook-Deegan, R.J.S. Racing for academic glory and patents: Lessons from CRISPR. 358, 874-876 (2017).

12. Egelie, K.J., Graff, G.D., Strand, S.P. \& Johansen, B. The emerging patent landscape of CRISPR-Cas gene editing technology. Nature Biotechnology 34, 1025-1031 (2016).

13. Egelie, K.J., Strand, S.P., Johansen, B. \& Myskja, B.K. The ethics of access to patented biotech research tools from universities and other research institutions. Nature Biotechnology 36, 495 (2018).

14. Mazzucato, M. The entrepreneurial state: Debunking public vs. private sector myths. (Anthem Press, 2015).

15. The Research Council of Norway (2015).

16. Stevens, H., Van Overwalle, G., Van Looy, B. \& Huys, I. Intellectual property policies in early-phase research in public-private partnerships. Nature Biotechnology 34, 504 (2016).

17. Walsh, J.P., Arora, A. \& Cohen, W.M. Effects of research tool patents and licensing on biomedical innovation. Patents in the Knowledge-based Economy 285, 286 (2003). 
18. Lei, Z., Juneja, R. \& Wright, B.D. Patents versus patenting: implications of intellectual property protection for biological research. Nature biotechnology $\mathbf{2 7}, 36$ (2009).

19. Czarnitzki, D., Grimpe, C. \& Toole, A.A. Delay and secrecy: does industry sponsorship jeopardize disclosure of academic research? Industrial \& Corporate Change 24, 251-279 (2015).

20. Evans, J.A. Industry collaboration, scientific sharing, and the dissemination of knowledge. Social Studies of Science 40, 757-791 (2010).

21. Blumenthal, D., Causino, N., Campbell, E. \& Louis, K.S. Relationships between academic institutions and industry in the life sciences - an industry survey. New England Journal of Medicine 334, 368-374 (1996).

22. Blumenthal , D., Campbell , E.G., Causino , N. \& Louis, K.S. Participation of LifeScience Faculty in Research Relationships with Industry. New England Journal of Medicine 335, 1734-1739 (1996).

23. Merton, R.K. The sociology of science: Theoretical and empirical investigations. (University of Chicago press, 1973).

24. Petrusson, U. Research and utilization. (University of Gothenburg, School of Business, Economics and Law, Gothenburg; 2016).

25. Brandl, B. \& Glenna, L.L. Intellectual property and agricultural science and Innovation in Germany and the United States. Science, technology, \& human values 42, 622-656 (2017).

26. Cook-Deegan, R. \& Heaney, C. Patents in genomics and human genetics. Annual review of genomics and human genetics 11, 383-425 (2010).

27. DESCA (2017).

28. Sohn, S.Y. \& Lee, M. Conjoint analysis of R\&D contract agreements for industryfunded university research. The Journal of Technology Transfer 37, 532-549 (2012).

29. Kretschmer, M., Singh, S. \& Meletti, B. in CREATe Working Paper (2018).

30. Eggington, E., Osborn, R. \& Kaplan, C. in UK Intellectual Property Office, Newport (2013).

31. O'Connor, S., Graff, G.D. \& Winickoff, D.E. (National Research Council, The National Academies, 2010).

32. Henry, C. \& Stiglitz, J.E. Intellectual property, dissemination of innovation and sustainable development. Global Policy 1, 237-251 (2010).

33. Andersen, B. \& Konzelmann, S. In search of a useful theory of the productive potential of intellectual property rights. Res Policy 37, 12-28 (2008). 